\title{
MUITO ALÉM DO ABANDONO: infâncias perigosas e a "justiça tutelar" em Pernambuco (1888-1892)
}

\author{
Gabriel Navarro de Barros*
}

\begin{abstract}
RESUMO: O presente artigo busca compreender a atuação da justiça tutelar diante do universo de meninas e meninos compreendidos pelo Estado como "potencialmente perigosos", em Pernambuco, entre os anos 1888 e 1892. Analisando fontes jurídicas e jornais, sugerimos uma reflexão acerca da excessiva utilização do conceito de abandono. Nosso estudo permite a compreensão de uma diversidade de categorias de infantes na época, reconhecidas pela justiça (especialmente pelos Juízes de Órfãos) e por instituições assistenciais a fim de identificar uma variedade de meninos e meninas como "riscos sociais".
\end{abstract}

PALAVRAS-CHAVE: Infância, Juízes de órfãos, Filantropia, Tutela.

\section{Far beyond abandonment: dangerous childhoods and "tutelary justice" in Pernambuco (1888-1892)}

\begin{abstract}
This article intends to understand the action of tutelary justice before the universe of girls and boys understood by the State as "potentially dangerous", in Pernambuco, between the years of 1888 and 1892. Analyzing legal sources and newspapers, we suggest a reflection on the excessive use of concept of abandonment. Our study allows the understanding of a diversity of infant categories of that time, recognized by justice (especially by Orphans' Judges) and by assistencial institutions to identify a variety of boys and girls as 'social risks'.

KEYWORDS: Childhood; Judges of orphans; Philanthropy; Guardianship.
\end{abstract}

\section{Más allá del abandono: infancias peligrosas y la "justicia tutelar" en Pernambuco (1888-1892)}

RESUMEN: El presente artículo busca comprender la actuación de la justicia tutelar ante el universo de niñas y niños comprendidos por el Estado como "potencialmente peligrosos", en Pernambuco, entre los años 1888 y 1892. Analizando fuentes jurídicas y periódicos, sugerimos una reflexión acerca de la excesiva utilización del concepto de abandono. Nuestro estudio permite la comprensión de una diversidad de categorías de infantes en la época, reconocidas por la justicia (especialmente por los Jueces de Huérfanos) y por instituciones asistenciales a fin de identificar una variedad de niños y niñas como "riesgos sociales".

PALABRAS CLAVE: Infancia; Jueces de huérfanos; Filantropía; Tutela.

\footnotetext{
* Doutorando em História no Programa de Pós-graduação em História da Universidade Federal de Pernambuco. Mestre em História pela Universidade Federal de Pernambuco. Contato: Departamento de História, Av. da Arquitetura, s/n, Centro de Filosofia e Ciências Humanas, Cidade Universitária, CEP: 50740-550, Recife-PE, Brasil. E-mail: b_navarro_2@hotmail.com.
} 
É salutar dispor cautela diante da tentativa de compreender que meninos e meninas efetivamente foram percebidos como sujeitos "potencialmente perigosos" à província e ao estado de Pernambuco nos anos que seguiram a abolição. As alcunhas de criança órfã ou abandonada não dão conta da multiplicidade de sujeitos que fizeram parte do mecanismo de assistência da tutela. Essas referências podem denotar divergências em seu entendimento e carecer de profícuas explicações diante da compreensão e complexidade que carregavam.

Alcileide Cabral do Nascimento ${ }^{1}$ aponta que a assistência institucional à infância, em Pernambuco, foi iniciada no governo de D. Tomás José de Melo, que administrou a capitania entre 1787 e 1789. De acordo com a historiadora, a instalação da Roda dos Enjeitados e da Casa dos Expostos ${ }^{2}$, situadas nas dependências da Santa Casa de Misericórdia, evidenciou um investimento de sensibilidade daquela sociedade diante da prática do infanticídio e do indiscriminado abandono de bebês.

Essa empreitada, no entanto, imbricou-se em múltiplas razões. A pesquisadora assinala que a regulamentação da exposição de crianças emergiu como um problema urbano, e não rural, dialogando com questões relativas à cidade e ao cuidado da população, que começava a aparecer na capitania como um alvo a ser posto sob análises capazes de distinguir quais grupos deveriam ser preservados, aumentados ou enclausurados. O desejo de civilizar “costumes bárbaros", bem como a constituição da necessidade de preservação da vida dos súditos, acabaram por estimular a nomeação das práticas de abandono de crianças como um problema da ordem pública.

Desta maneira, podemos compreender que a criança exposta, isto é, aquela que houvesse sido abandonada pelas ruas, depositada na Roda dos Enjeitados ou em frente a lares que, quem sabe, apresentassem indivíduos dispostos a arcar com o arrimo de uma pequena desconhecida, surge como um problema social, na capitania de Pernambuco, nas últimas décadas do século XVIII.

É apenas nos Oitocentos, todavia, que o infante exposto começa a ser percebido como um indivíduo que necessitava da intervenção do Estado para não se imiscuir em práticas que pudessem operar para negativar o plano social que se pretendia constituir. Junto a ele, aparece também a criança desvalida, geralmente associada à primeira categoria, que não era necessariamente enjeitada, mas simbolizava a falta de arrimo de adultos por ela.

A Casa dos Expostos apenas era capaz de arcar com o dispêndio necessário à criação de crianças somente até os sete anos, sendo esta idade o limite de permanência na instituição. Passado este tempo, elas deveriam ser dirigidas a outros estabelecimentos, responsáveis em discipliná-las para um cotidiano de trabalho ${ }^{3}$. 
Acontece que não só esses infantes eram vistos como elementos capazes de fomentar temor à "sociedade de bem". A associação do universo pueril à necessidade de intervenção estatal perpassava também a condição da orfandade. Esta poderia ou não estar associada ao quadro de desordem social. Torna-se diligente, neste sentido, distinguir os sentidos pautados por tal alcunha, uma vez que podiam apontar caminhos de entendimento destoantes e, por conseguinte, diferentes modos de assistência.

Uma menina ou um menino, cujo pai ou mãe tivesse falecido, se inseria na classificação de órfã ou de órfão, mas de um modo genérico. O Dicionário da Língua Portugueza, escrito pelo padre D. Rafael Bluteau e depois reformado pelo carioca Antonio de Moraes Silva, colocava a orfandade como “o estado do que não tem pai, ou mãe, por morte deles ${ }^{4}$ ”. Tal ausência acabava por implicar no "desamparo, que causa a falta do pai, ou mãe". Importante pontuar, todavia, que o termo "desamparo" é relacionado logo posteriormente com os sentimentos da tristeza e do luto ${ }^{6}$, que surgiriam através do contato com a morte e a perda dos pais.

Tais informações nos permitem afirmar que, nesta obra, não havia uma nítida estruturação de uma linha de pensamento que apontasse em que situações uma criança órfã mereceria ser reconhecida como uma "ameaça". O infante aparecia como um sujeito alheio a profundos contrastes sociais, condição que enfaticamente o despia de quaisquer especificidades capazes de marcar quais os caminhos que deveria trilhar quando a orfandade viesse à tona.

Não apenas nesse documento, contudo, podemos analisar o que era compreendido por infante órfão. Augusto Teixeira de Freitas, em sua obra Consolidação das Leis Civis, também nos auxilia a compreender os contornos que revelavam a figura de tal sujeito. É salutar, no entanto, perceber que a obra de Freitas trata desta questão sob um prisma jurídico, sob o qual se devia dispor de cuidados específicos. Neste sentido, seu entendimento se afasta do colocado pelo dicionário. De acordo com o jurista, a orfandade se fundamentava apenas na ausência da figura paterna, o que excluía o falecimento da mãe como um elemento capaz de impor essa classificação ${ }^{7}$.

Não acreditamos que os estudos de Teixeira de Freitas atuem para anular o significado apresentado por Antônio de Moraes Silva. Percebemos que se esse último marcava a compreensão da orfandade sob um aspecto mais geral da sociedade, Freitas a colocava em um espaço jurídico, cuja necessidade de amparo aparecia como um dever.

Assim, o infante, órfão de pai, aparecia como um sujeito cuja necessidade de arrimo tornava-se evidente, uma vez que a referência ao pátrio poder sustentava-se substancialmente 
na paternidade. A ideia corrente era que o progenitor deveria operar como o núcleo produtivo da família, garantindo sustento à esposa e a seus rebentos. De tal maneira, quando o falecimento ou a ausência do "pai de família" ficasse em evidência, suas crianças tornar-seiam órfãs, sendo a elas requisitado amparo.

Quando ocorria a morte de pais em famílias abastadas, o arrimo configurava-se fundamentalmente na escolha de um tutor para a criança, efetivado através da tutela testamentária ou da legítima ${ }^{8}$. O primeiro caso dizia respeito à validade da escolha do pai ${ }^{9}$ do infante que, em testamento, indicaria um tutor disposto a assumir a tutela de seu filho quando o mesmo ficasse órfão. Pereira de Carvalho elucidava que o progenitor do menor teria a melhor capacidade ${ }^{10}$ em escolher o indivíduo a ser encarregado de amparar o seu rebento, uma vez que os laços de sangue que os uniam e a afeição "natural" de um para o outro autorizavam esse direito $^{11}$.

A legítima, por sua vez, deveria ocorrer quando inexistissem tutores testamentários. Ela se pautava em garantir os cuidados da criança através da nomeação de parentes mais próximos para assumir a sua proteção. Tanto Freitas quanto Carvalho apontavam a mãe ou a avó do menor como as mais capazes de servirem como tutoras de seus filhos. Isto se elas assim quisessem e não tivessem "passado à segunda núpcias" 12 . Se qualquer uma delas viesse a casar-se novamente ou deixado de viver "em honestidade", deveria ser interditada a garantia de continuarem a ter como tutelados seus filhos ou netos. Como aponta Maria Aparecida Papali, essa concepção, que colocava a mãe ou a avó como sujeitos capazes de prover assistência a menores, fundamentava-se na simbologia do amor materno, uma vez que as próprias leis que regulavam as questões referentes às tutorias enunciavam a incapacidade da mulher em gerir a vida de crianças e jovens a serem tutelados, o que a colocava como um sujeito cuja percepção legislativa assumia rijos traços de misoginia ${ }^{13}$.

Sobre os que estavam proibidos de assumir a tutoria de uma criança, escrevia Carvalho:

\footnotetext{
São inábeis pela incapacidade física: $1^{\circ}$, os surdos e mudos; $2^{\circ}$, os cegos; $3^{\circ}$ os enfermos; $4^{\circ}$ os velhos. São inábeis pela incapacidade moral: $1^{\circ}$, os menores; $2^{\circ}$, as mulheres; $3^{\circ}$, os religiosos; $4^{\circ}$, os infames; $5^{\circ}$, os escravos; $6^{\circ}$ os sandeus e os desajuizados; $7^{\circ}$, os que seguem outra religião que não seja a católica romana; $8^{\circ}$, os condenados à morte.
}

A interdição aos portadores de inaptidão física era justificada pelo jurista por conta das limitações de força e agilidade, elementos fundamentais para a administração dos assuntos de interesse do órfão. No que toca os quesitos morais, os menores eram proibidos de assumir tutoria pelo fato de ainda se encontrarem sob o julgo do pai ou do próprio tutor. Portanto, não 
é de se estranhar que um jovem que ainda poderia ser tutelado assumisse os cuidados de uma criança ou de outro sujeito cuja idade pudesse, inclusive, aproximar-se ou até ser superior à sua.

Aos religiosos professos era também negado o direito. "Morrendo para o mundo" adentrando em ordenações monásticas, cabia distanciar-se dos assuntos seculares e investir em práticas e pensamentos que os aproximassem de Deus. Compete distinguir que por religiosos eram reconhecidos aqueles que viessem a fazer uso da clausura. Aos eclesiásticos, que podiam contar com maior abertura na execução de funções civis, a tutela legítima era permitida $^{16}$.

Inseriam-se na categoria de infames aqueles que apresentassem condutas repreensíveis, como bêbados, "vadios", viciados em jogos, e os que fossem frutos de indivíduos traidores ou sodomitas. A eles era desaprovada a garantia de assumir o "amparo" de uma criança pelo fato de poderem tanto influenciar seus protegidos aos "maus hábitos", "herdados pelo sangue"17, quanto fazerem uso de seus recursos indevidamente.

Os sandeus - alcunha da época utilizada para designar aqueles que sofriam de distúrbios psicológicos severos - e "desajuizados” eram também interditados ao cargo de tutor, sob a justificativa que pautava a incapacidade de administrarem seus próprios bens. Também ficavam proibidos os escravizados ${ }^{18}$, porque além da pobreza e da condição jurídica, eram percebidos como indivíduos propensos ao desenvolvimento de hábitos nocivos, aprendidos na senzala e marcados pela "inferioridade da raça".

Os que não seguissem a fé católica romana também eram vetados da possibilidade em assumir tal cargo, por estarem associados a comportamentos que se afastavam das boas condutas religiosas. É tanto que aqueles que constituíssem relações afetivas duradouras e com a presença de relações sexuais sem o consentimento do casamento, também eram interditados. A condenação à morte, o autor colocava como inexistente no Brasil desde 1876, não deixando de pontuar, no entanto, que no passado, aqueles julgados a tal pena eram impossibilitados de serem tutores.

O gênero feminino era, então, inferiorizado ${ }^{19}$, colocado junto a categorias morais próximas à menoridade, a doenças mentais, à infâmia e à condição cativa. A mulher era representada como um ser incapaz de raciocinar em equidade aos homens, um sujeito "infantilizado" intelectualmente, propenso a sentimentalismos exacerbados. Esses elementos fundamentavam a inaptidão feminina à administração dos órfãos. Não é demasiado argumentar também que, as mulheres, na compreensão jurídica da época, estavam mais propensas a cometer imoralidades ${ }^{20}$, o que dificultava a atuação dessas como tutoras. 
Restava fundamentar a legitimação da tutoria feminina exclusivamente através do amor maternal. Carvalho era claro quando assinalava que mães e avós apenas deveriam atuar como protetoras devido a este sentimento. Explanando sobre a proibição das mulheres ao cargo de tutora, escrevia: "exceto as mães e avós, porque presumiu a lei que o afeto que elas têm pelos filhos e netos supriria qualquer falta de capacidade" 21 .

Sobre o sentimento maternal, o Diário de Pernambuco de 15 de maio de 1888, em um anúncio de remédio para crianças, anunciava:

Dizia Napoleão I que, educando-se a mulher preparava-se o futuro. E de fato. A mulher é o principal motor do desenvolvimento humano. Quanto mais virtuosa e ilustrada for, melhores e mais bem educados serão os homens. A mãe é a sentinela vigilante que vela a vida preciosa da criança, acompanhando-a, desde os primeiros vagidos até o momento em que, feito homem, transpõe os umbrais da vida real. $\mathrm{E}$ quantos desgostos, e que torturas angustiosas, os de uma mãe que vê seu ainda pequenino, sem ter expressões para dizer o que sente e, todavia, gemendo, chorando sob a influência de um incômodo que, muitas vezes, sabido a tempo, poderia ser debelado? Quem se recorda destas situações críticas, tão comuns ao viver de uma mãe, não poderá deixar de curvar-se respeitosamente ante a mulher - a personificação do devotamento, da abnegação e dos mais puros e grandiosos sentimentos que se aninham no coração humano! ${ }^{22}$

Ora, não é árduo inferir que o trecho acima incide justamente sobre a pretensa capacidade emocional das mães. Se a mulher era reconhecida pela "fraqueza" moral, em contrapartida, era ela percebida também como um ser capaz de expressar o mais "puro" sentimento de devotamento, incisivamente por conta da maternidade. Em nenhuma parte do texto há menção a qualquer qualidade feminina que não o zelo, a virtude cristã e a capacidade de abnegação e devoção em prol da maturação de seus filhos.

Quando a matéria aponta que "a mulher é o principal motor do desenvolvimento humano" 23 , ela o faz direcionando ao gênero feminino a capacidade de atuar com precisão na esfera doméstica. Como aponta Jacques Donzelot, ocorre, no fim do século XIX, a difusão do ideal de amor materno, sustentada na obrigação da vigilância da mãe sobre os filhos e incentivada pela classe médica, que punha a "sujeição" da mulher diante de sua cria como um meio de intervir no acesso da criança às influências exteriores e no controle das brincadeiras e dos movimentos da mesma ${ }^{24}$.

A "submissão" feminina, por conseguinte, acabava por favorecer tanto os médicos, que viam na atuação das mães a derrocada da medicina popular das comadres, quanto à própria mulher, que assumia maior importância nas funções maternas e no ambiente doméstico ${ }^{25}$.

A suposta capacidade feminina de suportar os desgostos, as torturas e as angústias da vida familiar legitimava a condição de nutriz, educadora e protetora dos filhos. Tanto, que no fim do século XIX é possível perceber a majoração dos cuidados referentes ao direcionamento 
de crianças ao trato das amas de leite, comportamento tão comum nas elites da Europa Ocidental e brasileiras. $\mathrm{O}$ amor de mãe justificava o aleitamento pela própria genitora e, quando ainda assim não fosse feito, recomendava-se que a escolha da ama fosse feita com muita diligência, uma vez que os hábitos nocivos poderiam ser herdados através do leite ${ }^{26}$.

Há, portanto, uma nítida elucidação do sofrimento como um elemento positivo a ser utilizado sobre as genitoras. A maternidade assumia um tom que apontava o feminino como capaz de suportar as agruras que compunham as relações familiares. Deste modo, cabia à ideal mulher a sujeição, a anulação de si mesma e o devotamento incondicional aos seus filhos, elementos que garantiriam "os mais puros e grandiosos sentimentos".

Detentoras de tanta capacidade em assumir o arrimo de seus filhos e netos, as mães e avós deveriam, então, ser colocadas como as primeiras opções na assunção da tutela legítima de suas crianças. Isso, caso estejamos falando de famílias abastadas. Esses menores órfãos não implicavam fundamentalmente em obstáculos frente à tentativa de ordenamento da nação. Não eram encarados pelo Estado como sujeitos "potencialmente perigosos" à sociedade, visto que sua mãe ou seus parentes geralmente apresentavam o arrimo material necessário para educá-los, sustentá-los, vesti-los e os afastarem da ociosidade e violência que emergia de espaços físicos reconhecidos como "vis".

Acontece, no entanto, que Pereira de Carvalho, após enumerar as categorias que deveriam ser interditadas de assumir tutorias, enfatizava que aos pobres também deveria ficar implícito tal veto:

Semelhantes tutores, além de não poderem perder na administração dos bens do pupilo o tempo que se lhes faz necessário para ganharem a sua subsistência, não teriam com que segurar a sua administração. ${ }^{27}$

Como é possível observar, a proibição de tutoria aos sujeitos que não gozassem ao menos de moderados recursos, fundamentava-se em um cálculo temporal. Este indicava as atividades referentes aos cuidados do órfão como capazes de exigir bastante tempo de seu tutor. De tal forma, a administração dos bens do pupilo poderia fazer com que o seu protetor pudesse reduzir suas atividades de trabalho, uma vez que o mesmo deveria ocupar-se em assuntos referentes ao infante. Esse arrefecimento acabaria por incidir em uma restrição material ainda maior a indivíduos que já se encontravam imersos na pobreza. Por outro lado, a justificativa do impedimento baseava-se também nos parcos recursos do tutor, que possivelmente não seriam capazes de assegurar uma boa criação ao menor.

A pobreza, neste sentido, anulava o direito de mães e avós em atuarem como tutoras de seus filhos e netos. Apesar de o amor materno ser reconhecido como um elemento de grande 
validade no trato de crianças e jovens, a ausência de recursos suscitava a necessidade de intervenção do Estado no trato desses meninos e dessas meninas. De tal maneira, podemos pontuar que apenas a orfandade não implicava na categorização de um infante como um sujeito "potencialmente perigoso" à sociedade.

A associação do órfão à figura da "criança ameaçadora" se sustentava mais na frágil condição material familiar do que em questões relativas ao pátrio poder, como pontuou Papali $^{28}$. É tanto que após o 13 de maio de 1888, muitos infantes, filhos de mulheres excativas, são retirados da convivência familiar e colocados sob a "proteção" de antigos senhores ou sujeito de posses, em detrimento da criação junto às mães libertas.

Neste sentido, podemos afirmar que a "assistência" à infância estava imbricada em uma lógica de regulamentação das famílias. A criança "perigosa" não estava descolada de um meio alheio a profundos contrastes sociais e raciais. São fundamentalmente os órfãos provindos de instituições familiares desprovidas materialmente que tornaram volumosos os números de crianças assistidas pelo instrumento da tutela. De tal maneira, não é legítimo pensar que a atuação do Estado se pautasse unicamente em auxiliar aquele infante encontrado em abandono $^{29}$. Se estes últimos representavam os "grandes males" que poderiam ser gerados nas mais tenras idades, era preciso evitar que os filhos de famílias pobres, tidos como propensos à "vagabundagem", viessem a assumir tais figuras, que inspiravam tamanho temor.

A prevenção social, pensamento próximo à noção de filantropia, que se constituiu, em terras brasileiras, na primeira metade do século XIX, como nos lembra Maria Luiza Marcílio $^{30}$, era o fundamento que guiava a atuação das instituições de assistência à infância. Não apenas combater, mas evitar os "males", bem como fazê-los produtivos à sociedade, era o que valia. O pensamento filantrópico se distinguia do caritativo, típico dos tempos coloniais, justamente por assumir o desejo de investir em grupos tidos como "improdutivos" para, posteriormente, percebê-los como forças férteis ao desenvolvimento da sociedade.

Os Juízos de Órfãos, neste sentido, operaram, nos anos que seguiram a abolição, para retirar crianças e jovens da convivência junto a famílias pobres, no intuito de prevenir a majoração de infantes à nação por poder herdarem hábitos nocivos, "inerentes" à pobreza e também à "fragilidade da raça", como a "preguiça", o "desregro" da sexualidade e a "vagabundagem". Um infante sem o arrimo do pai e cujos parentes fossem desprovidos materialmente, era percebido pelos juízes como um ser que inspirava desordem, um alvo a ser "assistido" e disciplinado. Filho de uma ex-cativa, então, "duplamente temerário", pela inferiorização que implicava a sua cor.

Esses pequenos sujeitos possuíam o poder de atuar como efetivos obstáculos à tentativa 
de ordenamento que se imiscuía pela sociedade. Através do roubo, da prostituição de seus corpos, cometendo assassínios ou "vagabundando", operavam para criar uma paisagem de imoralidade que contrastava com o bem quisto progresso das últimas décadas do século XIX. Assim, crianças expostas, infantes desvalidos, menores encontrados em "vadiação" e órfãos de famílias pobres ou libertas eram compreendidos como sujeitos ameaçadores à ordem que o Estado tentava impor. Esses meninos e meninas, de tal forma, deveriam ser encaminhados a um cotidiano de trabalho que os pusesse longe da ociosidade e tentasse fazer deles sujeitos produtivos. A tutela dativa, neste sentido, se configurou como um mecanismo de assistência capaz de abranger pequenos corpos em situações de "risco", fossem esses pertencentes a meninos ou meninas.

O mecanismo da tutela dativa operou tanto com garotas quanto com garotos, além de aproximar-se efetivamente da população negra, então liberta. Esse instrumento jurídico diferenciava-se tanto da assistência promovida pela Colônia Isabel e pela Escola de Aprendizes Marinheiros, quanto das fábricas, por contar com uma grande diversidade de crianças e jovens em seu funcionamento, além de não legar a esses pequenos sujeitos a clausura em espaços físicos específicos.

No direcionamento de menores "potencialmente perigosos" à assistência de tutores, os Juízos de Órfãos dispunham do auxílio da polícia, que, após coagir pequenos "vagabundos", os dirigia para os magistrados; a Casa dos Expostos, que operava no recolhimento de crianças, através da Roda dos Enjeitados; de setores da imprensa, que faziam circular a boa ação que era cuidar de um menor em estado de orfandade; e de uma parcela da população que contasse com recursos para "amparar" um infante.

As tutelas dativas contaram com o trabalho e a disciplina como instrumentos dispostos a criar hábitos e sujeitos em consonância com os ideais de disciplina. Segundo Pereira de Carvalho, dever-se-ia dar tutores aos órfãos ricos, mas também aos pobres e até mesmo aos expostos $^{31}$. Essa prerrogativa baseava-se enfaticamente na capacidade filantrópica do mecanismo de tutela, que operava no meio social com o intuito de controlar o comportamento de garotos e garotas compreendidos como "potencialmente perigosos" à configuração social que pretendia se instalar no solo brasileiro.

Distanciar crianças e jovens da ociosidade, pondo-os sob os cuidados de tutores dispostos a criá-los sob as premissas do trabalho e da disciplina, configurava-se como uma estratégia cujo fito se pautava na tentativa de "adestramento" de corpos pueris no combate ao desperdício de suas capacidades.

Como podemos perceber no texto de Carvalho, a tutoria dativa não apenas operava para 
evitar a eclosão de agitações negativas no seio da sociedade, representadas sobretudo pela presença de crianças inseridas no universo da criminalidade. Sua finalidade se pautava, sobretudo, no aproveitamento da energia do menor tutelado para o progresso moral e econômico da nação:

\begin{abstract}
Ainda que a Ord. do liv. $1^{\circ}$, tit. 88 , e a do liv. $4^{\circ}$, tit. 102 , mandão dar indistintamente tutor a todos os órfãos, sem fazerem diferença dos ricos e dos pobres, contudo raras vezes se nomeia tutor aqueles que não tiveram legitima, porque em não havendo emolumentos esquecem as obrigações e os deveres mais importantes. O que daqui resulta é ajuntar-se à pobreza a falta de educação e um total desamparo em uma idade em que tanto se precisa de um diretor. E que pode esperar a sociedade de milhares de indivíduos que, perdendo os autores de sua existência nos mais tenros anos da sua infância, não acharão um braço benfazejo que os desviasse da estrada do crime, ensinando-lhes a da virtude? A sociedade deverá dar-se por satisfeita se esses seus abandonados filhos se limitarem a aumentar o número dos ociosos e se não abalançarem a toda a qualidade de excessos. Se o interesse social exige que se punam severamente os ociosos, também a razão e a justiça desaprovam o seu castigo enquanto se não puserem os meios de se evitar esse mal. Haja todo o cuidado em se darem tutores aos órfãos pobres, e a lei terá menos delitos a punir, a agricultura maior número de braços a empregar, e os ofícios e as artes florescerão consideravelmente ${ }^{32}$.
\end{abstract}

O texto, como é possível observar, atentava à necessidade de nomear tutores às crianças e infantes órfãos que não houvessem sido acolhidos por tutelas legítimas, isto é, que nenhum de seus parentes se dispusessem ou fossem capazes de assumir legalmente os cuidados na criação do menor. Não havendo, segundo o texto, grandes vantagens de amparar um infante nessas condições, a tutela dativa era colocada como rara. Nos parece que a fala do jurista opera mais em um sentido de estimular a prática de criação e educação de menores "perigosos" do que efetivamente simbolizar a raridade dessa prática social, que efetivamente era comum ${ }^{33}$.

O direcionamento de meninos e meninas a esse mecanismo operou no sentido de aproximar a sociedade junto aos princípios da ordem e da prevenção social, elementos próprios ao pensamento filantrópico da segunda metade dos Oitocentos. Como aponta o documento citado acima, era na infância que se precisaria de um "diretor" capaz de salvaguardar o destino de um futuro adulto. O tutor era o sujeito a quem cabia assumir esse papel, devendo auxiliar garotos e garotas a evitarem o caminho junto à "estrada do crime", bem como a ensinar-lhes boas virtudes. Tentava-se, com isso, garantir não apenas o sucesso moral e material do tutelado, mas a segurança da população.

Deste modo, se fazia necessária muita caução quando a escolha de um protetor apto a fornecer amparo a um infante "perigoso" se fizesse evidente. Além de ter de ser considerado um indivíduo idôneo, deveria o mesmo assumir a educação da criança que estivesse disposto 
a amparar, evitando que a mesma adentrasse no universo da ociosidade.

O que estava em jogo não era unicamente a tentativa de evitar a majoração da desordem que esses meninos e essas meninas pudessem causar, mas uma estratégia que visava fazer desses corpos infantis e jovens elementos não dispendiosos ao Estado, capazes de governarem a si mesmos e auxiliar no desenvolvimento da sociedade. É tanto que Pereira de Carvalho afirmava que a escolha de bons tutores para menores reconhecidos como riscos sociais era capaz de fazer a "lei ter menores delitos a punir, a agricultura maior número de braços para empregar e os ofícios e as artes prosperarem" 34 .

Por conseguinte, podemos perceber que o combate a infâncias "ameaçadoras" não se pautava unicamente na coerção de menores, tampouco responsabilizava excepcionalmente esses indivíduos por se encontrarem em tais condições. Interessante atentar em como a fonte coloca a responsabilidade do futuro de meninos e meninas também nas mãos dos tutores e do Estado.

Afirma que é do interesse social que se puna severamente a ociosidade, mas que na coação de um sujeito encontrado nesta condição, "também a razão e a justiça desaprovam o seu castigo enquanto se não puserem os meios de se evitar esse mal” ${ }^{35}$. Assim, não era justo punir diligentemente esses menores se a eles não fossem dirigidas políticas capazes de lhes afastar do mal da "vadiagem". Esta questão dialoga nitidamente com o que vimos anteriormente, quando é assinalada a culpa que o Estado assumia frente à persistente presença das práticas de "vagabundagem".

O mecanismo jurídico da tutela dativa, neste sentido, foi um instrumento que possibilitou a entrada de crianças e jovens em estado de "vagabundagem" no mundo do labor. Através dele, os Juízos de Órfãos atuaram como instituições capazes de gerenciar questões relativas ao direcionamento de garotas e garotos "perigosos" ao cuidado de tutores e ao trabalho.

Para isso, contavam com o dispositivo de poder da caridade $^{36}$. Pensar o exercício caritativo, neste sentido, nos permite assinalar a possibilidade de indivíduos atuarem em vista da assunção de uma posição moral bem quista na sociedade. Sujeitos poderiam se inserir em uma rede de competições cujo objetivo estava circunscrito à adjetivação dos seus praticantes como pessoas de "bom coração", cuja benevolência auxiliava tanto as estratégias de controle social quanto afirmava a fé daqueles que dela faziam uso. É tanto que os jornais da época contavam com propagandas aconselhando a população a tomar a medida profícua de trazer uma criança órfã ao seu lar, para que fosse sustentada e cuidada sob os preceitos cristãos do amor e do altruísmo. 
No dia vinte e três de maio de 1890, por exemplo, o jornal A Epocha dedicava uma extensa nota - escrita pelo Dr. Ennes de Souza - honrando as crianças da nação, esses "seres fracos por excelência”, que encontrariam na República a mais previdente proteção, efetivada pelo arrimo do corpo e a educação da alma ${ }^{37}$. À infância, o Estado deveria conceder a fonte pura dos bons costumes e do civismo. Nessa fase da vida é que se cultivariam os melhores sentimentos de amor à pátria, então aí é que seria possível incutir a sadia crença do dever para com a nação, uma vez que isso repercutiria para as novas gerações.

O cuidado com os órfãos aparece como um elogio à administração republicana, que entendia o amparo a essas crianças como sinônimo de desenvolvimento social. Observemos:

Ampare o órfão, dando-lhe o ensino das artes e dos ofícios e a instrução primária, ou recolhendo-os em asilos ou auxiliando aqueles que caritativamente os tomam sob sua paternal tutela. E terá por esse modo o governo da República feito jus ao reconhecimento de todos os homens de coração, de todos os beneficiados e de todas as geraç̃̃es que se forem sucedendo na escola do melhoramento social. ${ }^{38}$

Analisando o texto, é possível perceber que o governo republicano não deveria proteger os órfãos unicamente em nome do preceito cristão da caridade. O que está em jogo aqui é a necessidade de ordenamento social. Era papel do Estado Republicano garantir paz às famílias, intervindo efetivamente nas relações familiares em defesa da sociedade. $\mathrm{O}$ amparo aos órfãos, através do ensino das artes e ofícios, da educação primária, do recolhimento em instituições e da proteção caritativa daqueles que os colocassem sob sua tutela aparecem como necessidades que beneficiariam a sociedade e "todas as gerações que fossem sucedendo na escola do melhoramento social"39.

É salutar perceber como o texto apropria-se tanto da noção de filantropia quanto da de caridade para justificar a luta contra o desvalimento de crianças. Se nesse trecho da matéria a República não assume o papel de amparo à orfandade como uma escolha moral, um ato de benevolência próximo à tradição cristã, mas como uma obrigação em nome do "melhoramento social", ela dirige à população essa disposição, mirando-a como alvo na tentativa de produzir comportamentos dispostos a atender as necessidades de sujeitos “frágeis”. Ora, é possível perceber nitidamente que o termo caridade aparece apenas quando a fonte aponta o exercício feito por aqueles indivíduos capazes de tutelar um órfão ${ }^{40}$, deixandoo sob sua proteção: "aqueles que caritativamente os tomam sob sua paternal tutela" ${ }^{41}$. Esses, que acolhiam crianças ao seu pátrio poder, eram tidos como "homens de coração", a quem a República e a sociedade deveriam admirar.

A caridade aparece então como um elemento a ser motivado a fim de maximizar as estratégias filantrópicas de assistência à infância. Visando incutir na população o pensamento 
que pusesse o instrumento da tutela dativa como uma ação de amor cristão, contribuía, ao mesmo tempo, para reforçar os laços da ordem republicana. O discurso caritativo, neste sentido, atuava para legitimar práticas políticas laicas. Maria Luiza Marcílio assinala que o pensamento caritativo estava intrinsecamente imbricado ao pensamento religioso, tendo operado como fundamento máximo da assistência à infância no período colonial $^{42}$. Sem a preocupação de garantir retorno social, seu objetivo era espiritual, o de alcançar a graça no além por meio das boas obras. O pensamento filantrópico, por sua vez, se consolida no império, admitindo a necessidade de disciplina e criação de mecanismos de assistência capazes de prevenir e combater uma infância perigosa. Por conseguinte, era marcado pelo objetivo de minimizar os efeitos da violência social, necessitando assim, de um retorno positivo para a sociedade, das crianças e jovens sobre as quais se dedicava ${ }^{43}$.

Compreendemos que o discurso tradicional religioso, neste sentido, contribuía para legitimar novas necessidades de organização dos habitantes, pautadas em estratégias filantrópicas. Acontece aqui, aquilo que Michel Foucault explicou como retomada discursiva, isto é, um discurso que está no cerne de novos atos que retomam e transformam o significado daquilo que se disse para além de sua própria formulação ${ }^{44}$. Emprestam-se novos significados ao que poderia ser entendido por caridade, aproximando-a do pensamento referente à melhoria da sociedade. O discurso novo apropria-se do antigo, que por sua vez cede-lhe força. Por essa razão, nossa pesquisa não desvencilha o ideal caritativo do pensamento assistencialista filantrópico, típico da segunda metade do XIX. Preferimos aceitar que ambos atuaram no combate à uma infância "potencialmente perigosa".

O incentivo à caridade, por conseguinte, não era o único meio de estimular a difusão de tutelas dativas sobre órfãos pobres ou expostos. As leis orfanológicas eram bastante diligentes quanto aos incentivos destinados àqueles que pudessem se interessar em assumir a tutoria desses pequenos indivíduos. Aqueles que atuassem como seus protetores apresentavam o direito de, em troca dos cuidados prestados, usufruírem da força produtiva dos seus $\operatorname{acolhidos}^{45}$. Para os meninos, geralmente o serviço em alguns ofícios ou na agricultura se fazia presente, podendo também algumas atividades domésticas fazerem parte das suas atribuições. Às meninas, competia fundamentalmente o trabalho doméstico ${ }^{46}$.

Em várias ocasiões, os serviços prestados por esses menores era gratuito, não existindo portanto dever legal de depósito de soldada ao tutelado. Augusto Teixeira de Freitas, no artigo 268 da Consolidação das Leis Civis, explanava o seguinte sobre o assunto: "os que criarem órfãos antes dos sete anos não pagam soldada até esta idade, e podem, com faculdade do Juiz, servir-se deles por outro tanto tempo sem a pagarem"47. Esse ditame era nitidamente 
fundamentado nas Ordenações Filipinas, que era considerada a base do corpo legislativo em questões relativas à orfandade até 1916, quando entra em cena o Código Civil. Sobre a garantia de usufruir da força de trabalho de menores, apresentada acima, as Ordenações advertiam:

(...) se o Juiz de Órfãos achar, que algumas pessoas criaram alguns órfãos pequenos, sem levarem por sua criação algum preço, se a criação fizeram antes de os órfãos chegarem a idade de sete anos, a estes, que assim criaram, deixarão ter de graça outros tantos anos, quanto os assim criaram sem preço. ${ }^{48}$

Ambos os textos, portanto, advertiam que aqueles que cuidassem de órfãos que contassem com a idade limite de sete anos, poderiam se beneficiar, com o consentimento de um juiz de órfão, do trabalho do acolhido por um tempo equivalente à duração do período em que fora amparado.

O trabalho de Pereira de Carvalho delimitava mais especificamente quando o tutor apresentaria o direito de fazer uso da mão de obra de seu protegido gratuitamente:

Os juízes devem, com efeito, à vista das disposições das Ord. do liv. $1^{\circ}$, tit. 88 , e liv. $4^{\circ}$, tit. 102, dar tutores também aos órfãos pobres: antes da idade de oito anos, se os tutores os criarem e tratarem bem têm incontestavelmente o direito de empregá-los em seu serviço, independente do pagamento de soldada. ${ }^{49}$

Neste sentido, é possível compreender que Carvalho já demonstrava uma transformação nas leis referentes à orfandade entre as décadas de 1870 e 1880. Nesta última década, há um maior delineamento das disposições legais que permitiam aos tutores utilizarem dos serviços de seus tutelados, sem dispor, para isso, da assinatura de um contrato de soldada. Diferentemente do que havia sido apresentado por Teixeira de Freitas, pontuava-se a necessidade de os tutores tratarem e criarem bem os que estivessem sob a sua proteção. Além, efetivamente, da idade limite do infante passar de sete para oito anos.

Os deveres das leis, contudo, parecem não terem sido cumpridos à risca. A figura do menino Amâncio, menor exposto de doze anos, pardo, de pai e mãe desconhecidos, nos auxilia a compreender isso. O garoto foi tutelado em quatro de março de mil oitocentos e noventa e um, pelo capitão João do Rêgo Lima ${ }^{50}$, na cidade de Escada. O capitão estaria atuando junto à instituição do Juízo de Órfãos da cidade para afastar o menor da promiscuidade que poderia encontrar vagando pelo espaço físico da região.

Neste caso, podemos perceber que não consta, em nenhuma parte do termo de tutela, qualquer menção à necessidade de pagamento de soldada ao rapaz. O que, efetivamente, contraria o que se enunciava na legislação. O menino não havia sido acolhido até a idade de oito anos, devendo, portanto, o senhor João do Rêgo Lima garantir o depósito de um parco 
soldo ao menor. Esse argumento, por sua vez, encontra fundamento em outros textos legislativos, especificamente aqueles que tratavam sobre a tutela de crianças expostas. Freitas, a exemplo, recomendava em seu artigo 275:

Art. 275. Os expostos serão reputados como quaisquer outros órfãos, o Juiz poderá distribuí-los pelas pessoas que os-quiserem, até completarem doze anos; sem vencerem outro algum ordenado, que o da educação, sustento, e vestido. ${ }^{51}$

Assim, uma criança exposta, de acordo com os ditames legais, deveria ser encaminhada pelos Juízos de Órfãos ao cuidado de sujeitos dispostos a educá-la, sustentá-la e vesti-la. Aquele que assumisse a tutoria de um menor nessas condições ficaria isento do dever de remunerá-lo até que o mesmo atingisse a idade de doze anos. O artigo 275 se destaca na obra de Teixeira Freitas por duas razões. A primeira diz respeito ao fato dele focar sua atenção exclusivamente na criança exposta, isto é, aquela que tivesse sido enjeitada e abandonada pelas ruas ou depositada na Casa dos Expostos. É salutar reparar que nenhum dos ditames anteriores enfatiza a condição da exposição. A pobreza e a orfandade de menores é que surgiam como elementos a serem regularizados. Ambas, no entanto, destoam da última pelo fato de ainda poderem contar em seu núcleo com a participação de familiares - mesmo que apresentassem parcos recursos - para dar algum arrimo à criança.

Em segundo lugar, o artigo 275 estabelecia um período limite para a dispensa de pagamento de um "ordenado" ao exposto acolhido, que findava quando este alcançasse doze anos. Não havia neste item, que versava especificamente sobre a criança "exposta", a condição de o tutor poder usufruir do trabalho do menor caso o tivesse acolhido quando mais novo, como acontecia com qualquer outro órfão.

A adjetivação que implicava a exposição, portanto, marcava como a jurisdição dos Juízos de Órfãos deveria ser realizada. Ela diferenciava o infante exposto dos demais pelo fato deste apresentar menores condições ainda de se tornarem úteis a si e ao seu meio sem a intervenção dos juízes de órfãos e de sujeitos dispostos a acolhê-los.

Não queremos reduzir, com esse argumento, a caução que o Estado cedia diante daqueles menores que, não tendo sido enjeitados, se encontravam no seio de famílias tidas como incapazes de os sustentar e os educar ${ }^{52}$. Vale mais perceber aqui como, ao menos nas leis, a criança abandonada era assemelhada a um sujeito mais "perigoso" ainda, que deveria, a partir dos doze anos, receber auxílio financeiro a fim de não se inserir em um universo de "vagabundagem".

É possível ressaltar a distinção legal entre a criança órfã e a exposta também nos ditames apresentados por Carvalho. Observemos: 
Aqueles que sem vencerem estipêndio algum criam e educam os órfãos são dispensados de lhes pagarem soldada até a idade de dezesseis anos, e podem oferecê-los no recrutamento em lugar dos seus filhos: Alv. de 24 de Outubro de $1814, \S 7^{\circ}$. Acontece o mesmo aos que se encarregam dos expostos, depois de criados pelo concelho ou casa pia, pois que ficam dispensados de pagar-lhes soldada até os doze anos, tendo apenas obrigação de sustentá-los, educá-los, vestí-los: Alv. de 31 de Janeiro de $1775, \S 4^{\text {o }} .{ }^{53}$

Não é difícil inferir uma nítida diferenciação na fonte acima no que toca o trato legal entre um infante órfão e um enjeitado. O primeiro poderia ser criado pelo seu tutor até a idade de dezesseis anos sem a necessidade de efetivação de um termo de soldada. Em contrapartida, o menor contava com a possibilidade de ser recrutado ao serviço militar no lugar do filho legítimo de seu protetor - algo que também valia ao exposto. Este último, no entanto, tendo ou não sido assistido pela Casa dos Expostos, necessitaria ser encaminhado a algum indivíduo interessado em ampará-lo. O tutor, neste caso, ficaria isento da obrigação de prover salário à criança até que a mesma alcançasse doze anos de idade, apresentando somente a obrigação de sustentá-la, educá-la e vesti-la.

A força de produção desses menores, neste sentido, atuou como um artifício a ser explorado por seus tutores. Se havia a recomendação do Estado em moldar os corpos de menores "potencialmente perigosos", pondo-os sob hábitos e costumes consonantes à disciplina necessária ao trabalho e à educação, é possível assinalar que o mecanismo jurídico da tutela operou como um modo de garantir mão de obra gratuita a sujeitos que se colocavam como interessados em defender os interesses de meninas e meninos.

A exploração da força de trabalho de crianças e jovens, no entanto, não ocorreu unicamente de modo gratuito. Os contratos de soldada, que podiam vir assinados juntamente aos termos de tutelas dativas, se configuraram como instrumentos cujo objetivo assinalava o estabelecimento de uma nítida relação de trabalho entre o tutor e o menor que passasse a ser colocado sob a sua custódia. Mas não apenas isso. A jurisdição dos Juízos de Órfãos pernambucanos operou, entre 1888 e 1892, para fazer da soldada um mecanismo capaz de promover a "assistência" aos filhos de mulheres ex-escravizadas ${ }^{54}$, inserindo nas relações tutelares crianças negras que iam se despindo de uma conceituação jurídica fundamentada em uma lógica escravista, e que, paulatinamente aproximavam-se ao entendimento legal acerca da menoridade. Surge, portanto, um novo cenário, em que menores negros passam a compor os laços de tutelas com o direito de receberem soldos. Essa transformação incisivamente os afastava das condições colocadas aos ingênuos, pela Lei do Ventre Livre, em que tal possibilidade legal não era assinalada. Destarte, as crianças negras, filhas de mães libertas, 
estavam circunscritas aos corpos de leis escritos por Pereira de Carvalho e Agusto Teixeira de Freitas, e não mais às leis escravistas.

Essas meninas e esses meninos foram compreendidos como um problema social duplamente perigoso, pois estavam postos em um ponto de cruzamento que perpassava tanto a pobreza das famílias as quais estavam inseridos, quanto a negatividade que os cobria por serem as proles de uma população tida como potencialmente ameaçadora: a liberta. É por este prisma que tentaremos compreender como os Juízos de Órfãos fizeram da tutela um instrumento direcionado à "assistência" de crianças e jovens negros, que assumidamente foram percebidos pelo Estado como uma população pueril a ser controlada após a abolição da escravidão.

\section{Notas}

${ }^{1}$ NASCIMENTO, Alcileide Cabral. A sorte dos enjeitados: o combate ao infanticídio e a institucionalização da assistência às crianças abandonadas. São Paulo: Annablume: FINEP, 2008.

${ }^{2}$ Alcileide Cabral elucida que a miséria de muitas mães, o excesso de filhos de outras e a tentativa de salvar a honra de mulheres inseridas numa sociedade misógina, que entendia a virgindade como um símbolo ímpar da moral feminina, são elementos que impulsionaram a entrada de crianças na Casa dos Expostos. Não eram raros os infantes que morriam logo que adentravam na instituição. Os que sobreviviam eram direcionados para os cuidados das amas criadeiras que, mediante pagamento, ficavam responsáveis por eles até completarem sete ou oito anos. Ver: NASCIMENTO, Alcileide Cabral. A sorte dos enjeitados: o combate ao infanticídio e a institucionalização da assistência às crianças abandonadas. São Paulo: Annablume: FINEP, 2008.

${ }^{3}$ Dentre os estabelecimentos, podemos citar o Arsenal de Guerra, a Companhia de Aprendizes Artífices, mais tarde transformada em Escola de Aprendizes Marinhos, o Colégio dos Órfãos, o Colégio das Órfãs, a Colônia Orfanológica Isabel, o Liceu de Artes e Ofícios e os Juízos de Órfãos.

${ }^{4}$ SILVA, Antonio Moraes. Diccionario da lingua portuguesa. Lisboa: Typographia Lacerdina, 1813.

${ }^{5}$ Idem.

${ }^{6}$ Idem.

${ }^{7}$ FREITAS, op.cit., 1876, p.203.

${ }^{8}$ FREITAS, op.cit., 1876, p.193-217.

${ }^{9}$ CARVALHO, José Pereira de. Primeiras linhas sobre o processo orfanológico: parte segunda. Rio de Janeiro: Jacintho Ribeiro dos Santos Livreiro-Editor, 1880, p. 9.

${ }^{10}$ Augusto Teixeira de Freitas explica que os avôs e as mães também apresentavam o direito de decidir os futuros tutores de seus netos e filhos, mas não com a mesma legitimidade que se colocava aos pais. Em primeiro lugar, se cumpriria a decisão do pai. Caso o mesmo não tivesse feito um testamento explanando como o procedimento deveria ocorrer, o avô seria o responsável por efetivar essa documentação, ficando a mãe do menor como terceira opção para o cumprimento da norma. Ver: FREITAS, Augusto Teixeira de. Consolidação das leis civis. Rio de Janeiro: B.L GARNIER Livreiro-Edictor do Instituto Histórico, 1876

${ }^{11}$ CARVALHO, op. cit., 1880 , p. 9-10.

${ }^{12}$ Freitas (1876) assinalava que podia acontecer isso, uma vez que existiam brechas legais indicando a não nomeação de padrastos.

13 Sobre as implicações misóginas do direito no século XIX, ver CAULFIELD, Sueann. Em defesa da honra: moralidade, modernidade e nação no Rio de Janeiro (1918-1940). Campinas: Editora da UNICAMP, 2000.

${ }^{14}$ CARVALHO, op. cit., 1880 , p.63-67.

${ }^{15}$ Sobre as particularidades do clero regular, consultar SANTOS, Gustavo Augusto Mendonça dos. Transgressão e cotidiano: a vida dos clérigos do hábito de São Pedro nas freguesias do açúcar em Pernambuco na segunda metade do século XVIII (1750-1800). Dissertação (Mestrado em História). Universidade Federal Rural de Pernambuco, 2013. 
${ }^{16}$ CARVALHO, op. cit., 1880, p.63-67.

${ }^{17}$ A ideia dos hábitos serem herdados pelo sangue fazia parte da Teoria dos Fluxos, que apontava a inserção de líquidos, como o sangue, o leite ou o sêmen, no corpo humano, era capaz de provocar uma "degeneração" dos comportamentos do indivíduo. Ver: DONZELOT, Jacques. A polícia das famílias. 2. ed. Rio de Janeiro: Edições Graal, 1986.

${ }^{18}$ Apesar da categoria de escravizados se encontrar fora de nosso recorte temporal, preferimos manter o texto de Pereira de Carvalho - referente a uma década anterior, mas que ainda sustentava a jurisdição dos Juízos de Órfãos após 1888 em diversos aspectos - para aguçar a nossa percepção diante dos significados que assumiam o gênero feminino nesse corpo legislativo.

${ }^{19}$ Sobre os gêneros como construções culturais, ver: SCOTT, Joan Wallach. Gênero: uma categoria útil de análise histórica. Educação \& Realidade. Porto Alegre, vol. 20, nº 2, jul./dez. 1995.

${ }^{20}$ CAULFIELD, op.cit., 2000.

${ }^{21}$ CARVALHO, op. cit., 1880,p.65-66.

${ }^{22}$ ARQUIVO EDGAR LEUENROTH. Diário de Pernambuco, 15/05/1888, p.8.

${ }^{23}$ Idem.

${ }^{24}$ DONZELOT, Jacques. A polícia das famílias. 2. ed. Rio de Janeiro: Edições Graal, 1986.

${ }^{25}$ Idem.

${ }^{26}$ Idem.

${ }^{27}$ CARVALHO, op. cit., 1880, p.69.

${ }^{28}$ PAPALI, op.cit., 2003.

${ }^{29}$ As contribuições de PANTER-BRICK and SMITH (2010) sobre o conceito de abandono são profícuas no sentido de indicar a possibilidade de crianças e jovens (representadas nos discursos policiais e das instituições assistencialistas genericamente como abandonadas) não viessem a ter sido efetivamente enjeitadas por suas famílias. Apesar de não contarmos com fontes que possam sustentar a possibilidade desses meninos e dessas meninas manterem relações com membros de suas famílias, mesmo habitando as ruas, assinalamos essa possibilidade. Ver: PANTER-BRICK, Catherine. Nobody's children? A reconsideration of child abandonment. IN: PANTER-BRICK, Chaterine and T.SMITH, Malcolm. Abandoned Children. Cambridge: Cambridge University Press, 2000.

${ }^{30}$ MARCÍLIO, Maria Luíza. História social da criança abandonada. São Paulo: Hucitec, 1998.

${ }^{31}$ CARVALHO, op.cit., 1880, p. 27-30.

${ }^{32}$ Idem, p. 27.

${ }^{33}$ AZEVEDO, op.cit., 1995.

${ }^{34}$ CARVALHO, op.cit., 1880, p. 27.

${ }^{35}$ Idem, p. 27.

${ }^{36}$ Sobre a afirmativa, ver: NASCIMENTO, Alcileide Cabral. A sorte dos enjeitados: o combate ao infanticídio e a institucionalização da assistência às crianças abandonadas. São Paulo: Annablume: FINEP, 2008.

${ }^{37}$ HEMEROTECA DIGITAL DA BIBLIOTECA NACIONAL, Jornal A Epocha, 23 de maio de 1890, p.2. Disponível em <http://memoria.bn.br/hdb/periodicos.aspx $>$. Acesso em dezembro de 2013.

${ }^{38}$ Idem, p. 2

${ }^{39}$ Idem, p. 2 .

${ }^{40}$ É diligente inferir aqui a associação que o jornal faz entre a orfandade e o desvalimento. O órfão aparece na matéria como o símbolo de cuidados estatais específicos. O apontamento da necessidade do ensino de artes e ofícios, da educação primária e do encaminhamento a asilos como sinal de amparo à criança órfã constitui uma nítida associação desta com a pobreza, uma vez que aos órfãos de famílias abastadas esse tipo de assistência, geralmente, não se fazia necessária.

${ }^{41}$ Idem, p. 2

${ }^{42}$ MARCÍLIO, op.cit., 1998.

${ }^{43}$ É de bom tom inferir que não percebemos os conceitos de caridade e filantropia como duas categorias indissociáveis, muito menos que ambos não possam ter coexistido conjuntamente por grande parte da história de nossa nação. Basta relembrar que em pleno século XXI, cuja política de assistência à infância se fundamenta no pensamento de bem-estar social, a caridade ainda se mantém como uma prática frequente. Como nos explica Koselleck, os tempos históricos não são completamente indissociáveis, podendo haver entre camadas temporais distintas, conexões que não simbolizam a imutabilidade de certas práticas, mas que as marcam em sua historicidade e na capacidade que apresentam de dialogar com esferas cronológicasdiferentes bem como em transformar os significados que as circundam. Ver: KOSELLECK, Reinhart. Futuro passado: contribuição à semântica dos tempos históricos. Rio de Janeiro: Contraponto Editora, 2006.

${ }^{44}$ FOUCAULT, Michel. A ordem do discurso. 14 $14^{\mathrm{a}}$ ed. São Paulo: Edições Loyola, 1996.

${ }^{45}$ AZEVEDO, op.cit., 1995. 


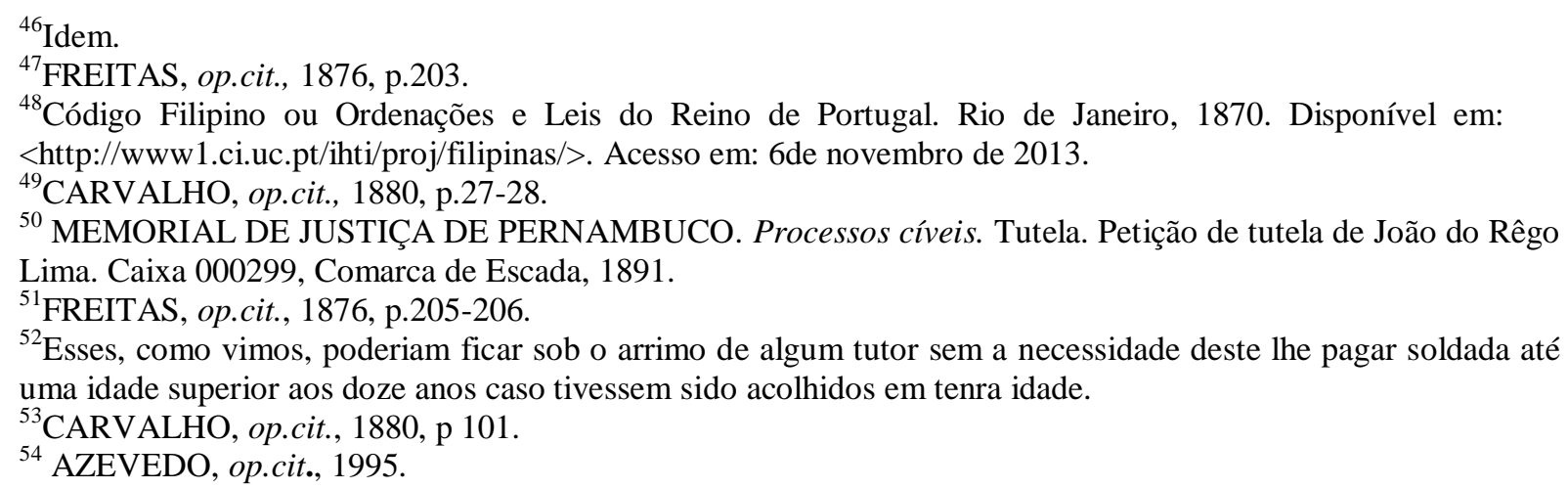

\section{Referências Bibliográficas}

ALBUQUERQUE JÚNIOR, Durval Muniz de. História: a arte de inventar o passado. Bauru, SP: Edusc, 2007.

ALBUQUERQUE NETO, Flávio Sá de Cavalcanti. A Reforma Prisional no Recife Oitocentista: da cadeia à Casa de Detenção (1830 a 1874). Recife: Dissertação de Mestrado. Universidade Federal de Pernambuco, 2008

ALENCASTRO, Luiz Felipe de. Vida privada e ordem privada no Império. IN: NOVAIS. Fernando A. e ALENCASTRO, Luiz Felipe de. (Orgs.). História da vida privada no Brasil: Império. São Paulo: Companhia das Letras, 1997.

ANJOS, João Alfredo dos. A roda dos enjeitados: enjeitados e órfãos em Pernambuco no séc. XIX. Dissertação (Mestrado em História) - Universidade Federal de Pernambuco, Recife, 1997.

AZEVEDO, Gislane Campos. "De Sebastianas e Geovannis": o universo do menor nos processos dos juízes de órfãos da cidade de São Paulo (1871-1917). Dissertação (Mestrado em História) - Pontifícia Universidade Católica de São Paulo, São Paulo, 1995.

Disponível

Os juízes de órfãos e a institucionalização do trabalho infantil no século XIX.

http://www.historica.arquivoestado.sp.gov.br/materias/anteriores/edicao27/materia01/.

Acesso em: setembro de 2011.

BARROS, Gabriel Navarro de. Crias do abandono, filhos da ordem: assistência, poder e resistência no Colégio dos Órfãos de Pernambuco (1835-1875). Monografia em História. Universidade Federal Rural de Pernambuco. Recife, 2010.

BASTOS, Ana Cristina do Canto Lopes. Nas malhas do judiciário: menores desvalidos em autos de tutoria e contrato de órfãos em Bragança SP (1889-1927). Tese (Doutorado em Educação). Campinas: Universidade Estadual de Campinas.

BRAGA, Vera Lúcia. Infância: assistencialismo e proteção em Pernambuco no início do século XX (1900-1930). IN: MIRANDA, Humberto e VASCONCELOS, Maria Emília (Orgs.). História da infância em Pernambuco. Recife: Ed. Universitária da UFPE, 2007.

BRANDÃO, Sylvana. Ventre livre, mãe escrava: a reforma social de 1871 em Pernambuco. $3^{\mathrm{a}}$. ed. rev. Recife: Ed. Universitária da UFPE, 2011.

BRITO, Rose Kelly Correia de. Trabalhar, casar e educar: a inserção social de meninas e moças enjeitadas no Recife (1840-1860). Monografia em História. Universidade Federal Rural de Pernambuco, 2009.

CARDOZO, José Carlos da Silva .et al. O Juízo dos Órfãos em Porto Alegre. Revista Justiça e História [On Line].Volume 9, número 17-18. 2011, p.6. Disponível em 
<http://www.tjrs.jus.br/export/poder_judiciario/historia/memorial_do_poder_judiciario/memo rial_judiciario_gaucho/revista_justica_e_historia/issn_1677-065x/v9n17n18/O_JUIZO.pdf>. Acesso em 20/04/2011.

CARVALHO, José Murilo de. A construção da ordem: a elite política imperial. $2^{\mathrm{a}}$ ed. Rio de Janeiro: Editora UFRJ, Relume-Dumará, 1996.

CARVALHO, José Pereira de. Primeiras linhas sobre o processo orfanológico. Rio de Janeiro: Jacintho Ribeiro dos Santos Livreiro-Editor, 1879.

Primeiras linhas sobre o processo orfanológico: parte segunda. Rio de Janeiro: Jacintho Ribeiro dos Santos Livreiro-Editor, 1880.

CASTILHO, Celso Thomas. Abolitionism matters: the politics of antislavery in Pernambuco, Brazil, 1869-1888. Berkeley: ProQuest, UMI Dissertation Publishing, 2008.

CAULFIELD, Sueann. Em defesa da honra: moralidade, modernidade e nação no Rio de Janeiro (1918-1940). Campinas: Editora da UNICAMP, 2000.

COSTA, Wendell Rodrigues. Instruir, disciplinar e trabalhar: a Sociedade dos Artistas Mecânicos e Liberais em Pernambuco e o Liceu de Artes e Ofícios (1880-1908). Dissertação (Mestrado em História) - Universidade Federal Rural de Pernambuco, Recife: 2013.

DONZELOT, Jacques. A polícia das famílias. 2. ed. Rio de Janeiro: Edições Graal, 1986.

FONSECA, Cláudia. Caminhos da adoção. São Paulo: Cortez, 1995.

FOUCAULT, Michel. A governamentalidade. In: FOUCALT, Michel. Microfísica do poder. 26. ed. Rio de Janeiro: Graal, 2008.

A ordem do discurso. 14ª ed. São Paulo: Edições Loyola, 1996.

História da sexualidade I: a vontade de saber. 17. ed. Rio de Janeiro: Graal, 2006.

História da sexualidade II: o uso dos prazeres. 11.ed. Rio de Janeiro: Graal, 2006.

Segurança, território e população. São Paulo: Martins Fontes, 2008.

Vigiar e punir: nascimento da prisão. 34. ed. Rio de Janeiro: Vozes, 2007.

FREITAS, Augusto Teixeira de. Consolidação das leis civis. Rio de Janeiro: B.L GARNIER Livreiro-Edictor do Instituto Histórico, 1876.

GAGER, Kristin Elizabeth. Blood ties and fictive ties: adoption and family life in early modern France. Princeton: Princeton University Press, 1996.

GOFFMAN, Erving. Manicômios, prisões e conventos. 7. ed. São Paulo: Perspectiva, 1999.

GUIMARÃES, Elione Silva. Tensões remanescentes das senzalas: análise de tutorias de menores afrodescendentes - Juiz de Fora - Final do século XIX e início do XX. IN: Revista Justiça \& História. $\quad \mathrm{N}^{\circ} \quad 9 . \quad$ Vol.5.Disponível em: http://www.tjrs.jus.br/site/poder_judiciario/historia/memorial_do_poder_judiciario/memorial judiciario_gaucho/revista_justica_e historia/issn_1676-5834/v5n9/?print=true. Acesso em: maio de 2013.

HEYWOOD, Colin. Uma história da infância: da Idade Média a época Contemporânea no Ocidente. Porto Alegre: Artmed, 2004.

KOSELLECK, Reinhart. Futuro passado: contribuição à semântica dos tempos históricos. Rio de Janeiro: Contraponto Editora, 2006.

KUHLMANN JR., Moysés. Infância e educação infantil: uma abordagem histórica. Porto Alegre: Mediação, 1998.

LIMA, Emmanuelle Valeska Guimarães de. "Não temos governo, não temos polícia...": os jornais e a crítica aos aparatos policiais no Recife oitocentista (1850-1874). Dissertação (Mestrado em História) - Universidade Federal Rural de Pernambuco, Recife, 2013.

MARCÍLIO, Maria Luíza. História social da criança abandonada. São Paulo: Hucitec, 1998. 
MAIA, Clarissa Nunes. Policiados: controle e disciplina das classes populares na cidade do Recife, 1865-1915. Tese (Doutorado em História). Universidade Federal de Pernambuco, 2001.

MATTOSSO, Kátia de Queirós. O filho da escrava. IN: DEL PRIORE, Mary. História da criança no Brasil. São Paulo: Contexto, 1991.

MORENO, Alessandra Zorzetto. "Vivendo em lares alheios": acolhimento domiciliar, criação e adoção na cidade de São Paulo (1765-1822). Tese (Doutorado em História). Universidade Estadual de Campinas, Campinas, 2007.

NASCIMENTO, Alcileide Cabral. A sorte dos enjeitados: o combate ao infanticídio e a institucionalização da assistência às crianças abandonadas. São Paulo: Annablume: FINEP, 2008.

e BARROS, Gabriel Navarro de. Crias do abandono, filhos da ordem: assistência, poder e resistência no Colégio dos Órfãos de Pernambuco (1835 a 1875). CLIO Revista da pesquisa histórica. $\quad \mathrm{N}^{\mathrm{2}} 28.1,2010.2$ Disponível em: http://www.ufpe.br/revistaclio/index.php/revista/issue/view/9/showToc. Acesso em: setembro de 2011.

PANTER-BRICK, Catherine and SMITH, Malcolm T. Abandoned children. Cambridge: Cambridge University Press: 2010.

PAPALI, Maria Aparecida Chaves Ribeiro. Escravos, libertos e órfãos: a construção da liberdade em Taubaté (1871-1895). São Paulo: Annablume: Fapesp, 2003.

SANTOS, Gustavo Augusto Mendonça dos. Transgressão e cotidiano: a vida dos clérigos do hábito de São Pedro nas freguesias do açúcar em Pernambuco na segunda metade do século XVIII (1750-1800).

SANTOS, Maria Emília Vasconcelos do. "Moças honestas" ou "Meninas Perdidas": um estudo sobre a honra e os usos da justiça pelas mulheres pobres em Pernambuco Imperial (1860-1888). Dissertação (Mestrado em História). Recife: Universidade Federal de Pernambuco, 2007.

SCOTT, Joan Wallach. Gênero: uma categoria útil de análise histórica. Educação \& Realidade. Porto Alegre, vol. 20, nº 2, jul./dez. 1995.

SILVA, Antonio Moraes. Diccionario da lingua portuguesa - recompilado dos vocabulários impressos até agora, e nesta segunda edição novamente emendado e muito acrescentado, por ANTONIO MORAES SILVA. Lisboa: Typographia Lacerdina, 1813.

SILVA, Wandoberto Francisco da. Guerreiros do mar: recrutamento e resistência de crianças em Pernambuco (1857-1870). Dissertação (Mestrado em História) - Universidade Federal Rural de Pernambuco, Recife, 2013.

STEARNS, Peter. A infância. Editora Contexto: São Paulo, 2006.

TEIXEIRA, Heloísa Maria. A criança no processo de transição do sistema de trabalho Brasil, segunda metade do século XIX. Disponível em: http://www.abep.nepo.unicamp.br/encontro2006/docspdf/ABEP2006_347.pdf. Acesso em: setembro de 2011.

VENÂNCIO, Renato Pinto. Famílias abandonadas: assistência à criança de camadas populares no Rio de Janeiro e em Salvador - Séculos XVIII e XIX. Campinas: Papirus, 1999.

VIANNA, Adriana de Rezende. O mal que se advinha - polícia e menoridade no Rio de Janeiro - 1910-1920. Rio de Janeiro: Arquivo Nacional, 1999.

VIEIRA, Hugo Coêlho. Aprendizes castigados: a infância sem destino nos labirintos do Arsenal de Guerra (1827-1835). Monografia em História. Universidade Federal Rural de Pernambuco. Recife, 2008. 